\title{
The Ethnological Counter-Current in Sociology
}

\author{
Fuyuki Kurasawa \\ La Trobe University
}

\begin{abstract}
As it enters the 21st century, sociology seemingly faces an exhaustion of theoretical and substantive approaches to deal with the pressing matter of cross-cultural research. This article suggests that one possible route out of the impasse lies in the rediscovery of an ethnological counter-current within sociology, a way of thinking that juxtaposes modern Western societies to other sociocultural contexts in order to better understand the full range of multiple modernities. In the first instance, it is contended that a comparative, intercultural tendency has played a determinant, albeit relatively neglected, part in the development of social research in the modern West; this tendency, which is identified as the 'ethnological imagination', has enriched and can continue to enrich sociological thinking. Second, the approach adopted by ethnologically informed sociologists is developed with the help of the hermeneutical tradition, in order to establish some of the foundations of an intercultural sociology.
\end{abstract}

keywords: culture $\uparrow$ ethnology $\uparrow$ hermeneutics $\uparrow$ modernity sociology

Ethnology is not a specialty defined by a particular object, 'primitive' societies; it is a way of thinking, one which imposes itself when the object is 'other', and demands that we transform ourselves. Thus we become the ethnologists of our own society if we distance ourselves from it. (Merleau-Ponty, 1960: 150)

One may investigate how particular human societies differ from one another. One may also investigate how all human societies resemble one another. Strictly speaking, these two research preoccupations are inseparable. Anyone seeking a clear picture of the similarities in all societies - the universal features

International Sociology $\downarrow$ March $2000 \downarrow$ Vol 15(1): 11-31

SAGE (London, Thousand Oaks, CA and New Delhi) [0268-5809(200003)15:1;11-31;012086] 
of human society - must be able to draw on a great wealth of knowledge, available in his own society, about the variations possible in human societies. (Elias, 1978: 104)

The sociologist who chooses to study his [sic] own world in its nearest and most familiar aspects should not, as the ethnologist would, domesticate the exotic, but, if I may venture the expression, exoticize the domestic, through a break with his initial relation of intimacy with modes of life and thought which remain opaque to him because they are too familiar. In fact the movement toward the originary, and the ordinary, world should be the culmination of a movement towards alien and extraordinary worlds. (Bourdieu, 1988: xi-xii)

\section{Introduction: The Neglect of the Ethnological Imagination}

At the end of our century, sociology appears to face an impasse. On one hand, in light of the globalizing tendencies that are reshaping the world's sociopolitical and economic landscape, the need for cross-cultural research has never been greater. On the other hand, the perils of such endeavors have been accentuated by the so-called 'crisis of representation' in the human sciences, itself prompted by the perceived ethnocentric bias of most Western approaches to the study of non-Western societies and cultural contexts. As a result, most sociologists have reacted in two distinct ways. Overlooking the classical heritage, some have simply retrenched behind seemingly safe disciplinary barriers - a situation anticipated by Gouldner, who in the early 1970s merely repeated conventional wisdom:

The very activities of the anthropologist require him to go to more exotic and romantic locales; sociology, however, remains, for the most part, a study of the familiar, the everyday, and the commonplace.... The anthropologist writes about extraordinary locales that have colour and vividness, in contrast to the sociologist's greater proclivity for the matter-of-fact and the prosaic. (Gouldner, 1973: 344-5)

Others, taking Lyotard's (1984) prescriptive report about the end of metanarratives to heart, have fallen back upon a prudent localism that focuses almost exclusively on Western manifestations of modernity. Glaringly, such a response risks nurturing not only what Elias (1987a, 1987b: xv-xvi, xxii) calls 'the retreat of sociologists into the present' but also, just as worryingly, their retreat to their own cultural lifeworlds. ${ }^{1}$

Regardless of how bleak it may at first appear, this impasse is by no means insurmountable. Both poles of the bind have been challenged by the existence of an important, albeit relatively neglected, current of intercultural sociology; designated as the 'ethnological imagination', it is 
discussed in the first part of this article. Nevertheless, the mere uncovering of an ethnological counter-current within sociology remains incomplete on its own, given that the overwhelming majority of contributions to cross-cultural research has proceeded with rather underdeveloped theoretical and epistemological frameworks. Consequently, the second part of the article draws upon the hermeneutical tradition to systematize some of the foundations of sociology's ethnological imagination.

Let me begin by posing a deceptively simple question: how is critical analysis accomplished, specifically radical interrogation of one's society and historical period? Although the answers could take numerous forms, Elias's (1987b) distinction between 'involvement' and 'detachment' is particularly well suited to our purposes. An involved critique employs another state as a normative guide to make sense of, and even possibly change, the existing social order. ${ }^{2}$ Philosophy has developed a plentiful supply of such devices of evaluative differentiation between, for instance, truth and falsehood, the ideal (what ought to be) and the real (what is), appearance and essence, transparency and opacity. Detachment, by contrast, aims to achieve a certain distance from one's social context, either historically, culturally or in both manners. A detached critique can itself be subdivided into genealogical (or historical) and intercultural (or ethnological) stands. While the first defamiliarizes the present by establishing a temporal gap with a past to which it is compared and contrasted, the second 'goes abroad' or 'looks elsewhere' to search for different illustrations of the human condition. ${ }^{3}$

In the latter half of the 20th century, the human sciences have often brought the genealogical mode of critique to bear on the here and now. Mills's (1959) 'sociological imagination' is nothing if not historical, for it envisages history as inextricably bound to any type of social inquiry. Certainly, it is to history (and reason) that Horkheimer (1972: 207-8) appeals in his well-known 'Traditional and Critical Theory', where questioning of the existing social order must be informed by an understanding of the sociohistorical conditions at its roots. Elias's (1994a) developmentalist approach to the study of civilizing processes should be mentioned in the same vein, because of its skill in defamiliarizing contemporary European societies through the portrayal of their own medieval past as a strange, virtually foreign history. ${ }^{4}$ More broadly, Foucault's (1965, 1977, 1978) Nietzschean studies of practices and rationalities functioning in different realms of social life, as well as Taylor's (1989) investigations into the philosophical sources of modern Western subjectivity, are among the most outstanding examples of genealogical critique through detachment. Despite obvious differences in epistemological bases and substantive findings, all of these analyses have historicized the present, showing how it has gradually emerged out of previous social configurations; far from 
being presumed to have always already existed, current beliefs and practices are shown to be ever-changing outcomes of sociocultural struggles between and among social groups holding competing worldviews. In other words, genealogy demonstrates how the here and now results from the narrowing down of the field of historical possibilities.

If its historical wing has been predominant within sociological circles, detachment has also been realized cross-culturally. Mostly overlooked or marginalized, the juxtaposition of self and other has come to inform sociology's ethnological imagination: the discipline's comparativist orientation, its use of non-Western social contexts (notably the 'primitive' and 'Oriental' conditions) as universes of cultural alterity against and through which Western modernity is interrogated. The modern West's self-constitution can thereby be perceived to be bound to other historico-cultural horizons, prompting the recognition of multiple modernities. ${ }^{5}$ By evoking The Sociological Imagination (1959), a discussion can ensue as to how an ethnological counter-current supplements Mills's historically steeped vision of sociology. Genealogical and intercultural dimensions of thinking can refract and play off each other, mutually enhancing our discipline.

On a more literal level, my choice of terms is quite deliberate. 'Ethnological' is preferred to 'anthropological' for two reasons: it is more general than what has come to be known as the discipline of cultural anthropology in the English-speaking world; also, it avoids a possible conflation with philosophical anthropology, the Continental tradition of reflection upon human nature (the essence of what makes us human). The category of the 'ethnological' hereby encompasses sociological research that compares and contrasts aspects of Western modernity to their corresponding realities in different cultural settings. 'Imagination' highlights the mythical character of the various constructs of cultural otherness (e.g. 'primitiveness' and the 'Orient') developed in the modern West. ${ }^{6}$ Sociologists do not necessarily propose the 'primitive' and 'Oriental' conditions as accurate representations of the societies and peoples to which they refer, but instead as mythical alter egos of Western modernity. ${ }^{7}$ By making sense of the latter's past, present and future, these alter egos assist its self-understanding.

Pace most recent sociological trends, let us take Mills's injunction seriously:

What social science is properly about is the human variety, which consists of all the social worlds in which men have lived, are living, and might live.... Byzantium and Europe, classical China and ancient Rome, the city of Los Angeles and the empire of ancient Peru - all the worlds men have known now lie before us, open to our scrutiny. (Mills, 1959: 132)

What if, then, we were to blur the boundaries between familiarity and 
estrangement, as well as between the ethnological and the sociological imaginations, to form a firmly intercultural sociology?

\section{Uncovering an Intercultural Counter-Current}

Sociology's cross-cultural tendency has contributed to the self-critique of Western modernity by stepping beyond the confines of our own frameworks of thinking and acting; indeed, it has helped to contextualize them in historical and cultural terms. The 'distancing effect' produced by encounter and engagement with other sociocultural formations thoroughly questions the modern West's here and now. It demands, moreover, that we face the queries which Gauguin, in what he considered his masterwork, posed at the end of the 19th century: 'D'où venons-nous? Que sommes-nous? Où allons-nous?' ('Where do we come from? What are we? Where are we going?'; see Gauguin, 1968). As Heller (1982: 4) insists, these three questions are pivotal for our purposes, touching the very stuff of human existence, history and culture, as well as the core of Western modernity itself. ${ }^{8}$

To elaborate, the ethnological imagination can be said to contain intercultural and intracultural facets. Interculturally, it problematizes the ethnocentric narrowness which cannot conceive of the diversity of human possibilities beyond the boundaries set by Western modernity. It does so by relativizing the latter as one sociohistorical constellation among many others. Taylor (1985b: 129) usefully contends that:

We are always in danger of seeing our ways of acting and thinking as the only conceivable ones. That is exactly what ethnocentricity consists in. Understanding other societies ought to wrench us out of this; it ought to alter our self-understanding. (see also Dumont, 1977: 18, 36, 1986: 8-9; Fuchs, 1993: 108; Merleau-Ponty, 1953a: 114-15)

Intraculturally, the apparent 'givenness' or 'naturalness' of existing modern Western beliefs, norms and practices - commonly perceived as removed from the sociohistorical domain - is disputed. To borrow Castoriadis's terminology, the 'self-instituting of society', the creation and putting into institutions of modes of conduct and systems of beliefs by humanity itself without referring to any extra-social sources or forces (nature, god, Geist, etc.), can be vigorously exposed.

Each of these facets has contributed to cross-cultural sociology, inspiring some of the most perceptive analysts of the modern condition in the Western world. In retrospect, we can now justifiably speak of a veritable counter-tradition, one whose sociological pedigree is equally long as it is distinguished. Among European thinkers, Montaigne is perhaps the first to have given form to this ethnological sensibility in the modern era. The 
words of his famous essay on cannibals, in which his cultural perspectivism comes forth as a potent motif of critique, still resonate with us four centuries later:

I think there is nothing barbarous and savage in that nation, from what I have been told, except that each man calls barbarism whatever is not his own practice; for indeed it seems we have no other test of truth and reason than the example and pattern of the opinions and customs of the country we live in. (Montaigne, 1948: 152)

During the Enlightenment, cross-cultural thinking became a widespread device among sociologically minded authors. Montesquieu's Persian Letters (see Montesquieu, 1973) continues to stand as one of the landmarks of the ethnological imagination; by observing Parisian society through the eyes of Usbek, an 'exotic' foreigner, Montesquieu relentlessly estranged the customs and rituals of Parisian society. ${ }^{9}$ Rousseau, the great and uncompromising critic of European civilization, advanced the figure of the 'civilized savage' to render his surroundings unfamiliar and question its basic raison d'être. Further, it should not be forgotten that in his magisterial Outlines of a Philosophy of the History of Man, Herder strongly defended cultural pluralism by portraying each culture as a plant to be nurtured in a specific area of the great garden of humankind (see Herder, 1966).

Properly speaking, even the canonical triumvirate of founders of the sociological discipline cultivated unabashedly cross-cultural interests. Marx denaturalized capitalism and studied the revolutionary forces it unleashed on Western Europe by referring to other ways of structuring production (e.g. primitive communism, the Russian agricultural commune, the Asiatic mode of production). Later in the 19th century and in the beginning of the 20th century, Durkheim and Weber were responsible for major programs of intercultural research aimed at shedding light on the institutions of modern Western societies; the first immersed himself in the universe of 'primitive' cultures, while the second developed a comparative sociology of world religions attuned to Asian beliefs.

Between the 1910s and 1940s, Park (1952) spurred sociology's ethnological counter-current onward thanks to the pioneering application of ethnographic techniques to describe the city as a 'social laboratory' in which different cultural groups lived side-by-side, occasionally mingling with one another. Not to be forgotten, some of Park's other essays (Park, 1950a, 1950c, 1950d) exemplified an intercultural sensibility in the comparative descriptions of different societies and civilizations that were used to arrive at the defining traits of Western modernity and, more specifically, of American society. A few years later, refusing to segregate cultural anthropology from 'mainstream' sociology, Mills's (1959: 132-8) 
memorable intervention urged our discipline to cultivate comparative research in order to value what he called 'the human variety'. In more recent times, it has been in France that the impact of the ethnological imagination has been most felt among social thinkers. If the historical and political factors accounting for this prominence cannot be discussed here, at least two intellectual causes should be briefly mentioned: the ongoing influence of the Durkheimian tradition, which scarcely separates social anthropology and sociology; and, from the 1950s to the 1970s, the massive repercussions of Lévi-Strauss's structuralist enterprise granted intercultural critique an almost unprecedented presence and prestige.

The ramifications of this consistent cross-cultural presence within the French milieu of the second half of the 20th century have been considerable and wide ranging. Lévi-Strauss's (1968: 117) technique de dépaysement, of cultural disorientation achieved by the ethnologically minded thinker, became a generational beacon and affected the human sciences in toto: in philosophy, Derrida (1978: 282) incessantly deconstructed the logocentrism of Western metaphysics by underlining its ethnocentric essence; religious studies were recast by Eliade's (1960) comparative analyses of different societies' mythological systems; Clastres's (1977) political anthropology opened up new areas of investigation by viewing 'primitive' societies as being organized 'against the state' rather than lacking statist structures. Spanning several domains, Foucault seized upon the critical potential of the ethnological mindset early on, positioning it in the midst of his archeologies and genealogies of modern culture. ${ }^{10}$ In recent times, Bourdieu has been the best-known sociological practitioner of the ethnological counter-current. His advocacy of an epistemological break with the 'doxa' of our society is inconceivable without a cross-cultural perspective, which in his case originated from his early fieldwork among the Kabyle of Algeria. Though switching his object of analysis from 'alien' to 'familiar' fields of power, Bourdieu has preserved his ethnological outlook more or less intact (Bourdieu, 1979: 587-8, 1990: 18, 20; Bourdieu et al., 1991: 251). Here can be pinpointed one of the keys to his oftremarked virtuosity, his ability to extract novel and telling insights about institutions and ritual modes of action in French social life.

Today, as the impasse within sociology festers, the discipline has largely spurned the ethnological imagination. By contrast, it has never been more vibrant within cultural anthropology (Marcus and Fischer, 1986), where two principal modes of stimulating analysis of Euro-American societies have been developed: some have concentrated on the histories of ideas and belief systems (Asad, 1993; Dumont, 1972, 1977, 1986, 1994), while others have been mainly concerned with archeologies of the emerging practices and sites that characterize Western modernity (Augé, 1995, 1998; Rabinow, 1996). ${ }^{11}$ Deplorably, most, if not all, of this work has passed 
unnoticed among sociologists, whose intercultural sensibilities are at a historical nadir. For this reason, and in the hope of reviving such sensibilities, the benefits and hermeneutical sources of the ethnological imagination should be explained.

\section{The Ethnological Imagination as an Intercultural Hermeneutics}

The 'distancing effect' that supports estrangement, even exoticization, of one's own sociocultural environment is by no means a sui generis or ex nihilo phenomenon. On the contrary, it is the outcome of a complex process of dialogical interaction between two or more cultural lifeworlds, a spirallike movement back and forth between these lifeworlds to draw out differences and similarities. The authors discussed in the previous section may have given certain clues as to the tenor of their ethnological sensibilities, yet none of them has offered a systematic or sustained account of the contents of the cross-cultural framework that guides their work. Even Bourdieu, whose foregrounding of the epistemological principles of his brand of 'reflexive sociology' (Bourdieu et al., 1991; Bourdieu and Wacquant, 1992) is unparalleled, provides a passing and mostly fragmentary treatment of these issues. To address such a deficit, I refer momentarily to the words of Merleau-Ponty with which this article opens. His statement crisply outlines the constituent elements of the ethnological 'way of thinking': the encounter with cultural alterity; self-transformation and distancing; and the re-examination of one's society. We can think with Merleau-Ponty, thereby elaborating the three interdependent analytical principles of an intercultural sociology: the outward turn, or moment of openness; 'in-betweenness', or moment of mediation; and the inward turn, or moment of reflexivity. The study of non-modern and non-Western cultures illuminates the study of Western modernity, and vice versa, since examining one prompts a reconsideration of the other. Sameness can be perceived in alterity and, of course, alterity in sameness.

The drive behind the ethnological imagination is fundamentally hermeneutical, for as has often been acknowledged, the effort to make sense of the other is simultaneously an effort at self-understanding (Calhoun, 1995: 44; Clastres, 1977: 17; Diamond, 1974: 100; Eliade, 1960: 9; Gadamer, 1994: 97; Ricoeur, in Lévi-Strauss et al., 1970: 64, 66; Ricoeur, 1974: 51; Taylor, 1985b: 129-30; Walzer, 1987: vii). ${ }^{12}$ Albeit concerned with portrayals of the non-Western and the non-modern cultures, the quest for an outside of Western modernity also represents a search for an alternative questioning of proximate and immediate social institutions. The ethnological imagination strives to create a critical hermeneutics of the modern experience, given that, as Taylor puts it, 'understanding is inseparable 
from criticism, but this in turn is inseparable from self-criticism' (Taylor, 1985b: 131). The critical component of the hermeneutical approach is additionally evoked in Horkheimer's (1972: 208) discussion of the dialectical tension between the need to understand the interpretations of the existing socioeconomic order (a society's self-identity) and that of questioning its entire structuring of human existence (see also Calhoun, 1995: $8-9)$. In this respect, openness, mediation and reflexivity, which correspond to the three ethnological moments enumerated above, can direct the return of the ethnological imagination at the heart of sociological endeavors.

Despite its obvious suitability, hermeneutics do not provide a wholly amenable perspective from which to reconstruct cross-cultural sociology. Two main adjustments have to be made. First, the hermeneutical tradition has primarily been oriented toward the historical dimension of interpretation, namely temporal distance that stems from the relationship between the immediate experience of the interpreter and the tradition of reception and interpretation (of a work of art, a text, etc.). By contrast, the ethnological imagination is primarily interested in cross-cultural interpretation, difference and identity being forged out of the dialogical relationship between one's representations of the modern West and its posited alter egos. Second, hermeneutics can be 'sociologized' by redirecting it from textual analysis to research on social life and the patterns of thought and action that compose the fabric of any given society.

\section{Openness and the Outward Turn}

Sociology's ethnological counter-current is initiated by our turning outward, our encounter with modes of social organization that exist beyond familiar cultural horizons. Whether as a work of art or an entire culture, no lifeworld can be properly be grasped in isolation, as a closed, discrete or completely auto-referential entity. Instead, it must be perceived as always already culturally open, shaped by complex histories of exchanges, borrowings, appropriations and impositions. The widely discussed idea of a 'hermeneutical circle' can serve as a trope for the ongoing sociological quest to make sense of a given society's self-identity; this process unfolds in the form of an interpretive activity that deciphers a culture's symbolic and material relations by observing corresponding sets of social relations in other cultural environments (Calhoun, 1995: 2, 35; Gadamer, 1994: 96-7, 247-8, 268, 302, 304-6, 361, 374, 385, 394-5; MerleauPonty, 1953a: 117, 1953b: 167; Park, 1950a: 4, 1950b: 39, 46-9; Rabinow and Sullivan, 1987: 7-8, 13; Ricoeur, 1981a: 61-2; Walzer, 1987: 32, 49). The ethnologically minded sociologist, then, continuously searches for sociocultural realities not enclosed in the immediacy of his or her time and the proximity of his or her locale. Alternative cultural imaginaries, such as 
primitiveness and the 'Orient', are consequently perceived as essential factors in the constitution of Western modernity.

Apart from this initial recognition of the openness of cultures, intercultural sociology must be willing to remain open, to be continuously receptive to what Gadamer terms the 'provocation' of difference. Incessantly evaluating certain findings against the realities of different histories and cultures, it must be ready to revise categories of analysis and substantive conclusions. In order to enrich and appropriately contextualize our research, it is incumbent upon us to seek actively after other, often unsuspected, experiences and possibilities outside of our familiar lifeworlds (Arnason, 1990: 206; Calhoun, 1995: 48-9, 84; Eliade, 1960: 7-9, 38; Gadamer, 1994: 17, 299; Merleau-Ponty, 1953a: 114-15, 1960: 150; Mills, 1959: 146-52; Rabinow and Sullivan, 1987: 20). Metaphorically, Taylor (1998: 111) describes the gains of such an outlook: 'When we escape from the prison of our perspective, the ground shakes under our feet, at least at the start.' Sociologists have a marked interest in escaping from such a prison, either through the figurative creation of a non-modern, nonWestern condition (the state of nature, primitiveness, the 'Orient', etc.), or yet again by literally leaving one's society to study another (the practice of fieldwork). Regardless of the preferred path, this shaking of the ground can be felt - and with it, the temporary sense of cultural disorientation caused by the meeting of cultural alterity. ${ }^{13}$

\section{Mediation and In-Betweenness}

The sociologist's outward turn is followed by a moment of mediation among different sociocultural settings. For hermeneutics, the discovery and acknowledgment of a temporal distance between the present and the past constitute the universe of understanding (Gadamer, 1994: 117, 128, 132, 165, 267-8, 296-7, 393, 472, 537; Ricoeur, 1981c: 144); interpretive alienation encourages reflection on the existence of disjunctures between current and traditional modes of understanding, between the interpreter and the interpretive tradition. ${ }^{14}$ Similarly, the sociologist's encounter with other cultures facilitates distancing his or her own horizons, thereby putting it into perspective. Such a process of fundamental interrogation can be fostered by the admission of a 'gap' between divergent histories, cultural self-definitions and modes of engaging with the world. The discovery of different yet internally legitimate forms of human organization that neither readily match nor are even derived from our own greatly qualifies assumptions of universality. Our lifeworld is correspondingly relativized, not equated with all others but situated as one configuration within the vast range of human possibilities (Bourdieu, 1977: 168, 233, n.16, 1990: 14; Bourdieu and Wacquant, 1992: 73; Clastres, 1977: 12-13; Eliade, 1960: 10, 12; Merleau-Ponty, 1953a: 114-15, 1953b: 
163-4; Mills, 1959: 146-52; Taylor, 1985a: 54, 1985b: 131; Winch, 1970: 78, 94, 99).

Yet cultural perspectivism is merely one of the prerequisites of crosscultural sociology. Hermeneutics goes a step further, contending that understanding does not merely emanate from the acknowledgment of what Ricoeur (1981a: 60, 1981b: 64) has termed 'alienating distantiation' (Verfremdung), the seemingly undecipherable strangeness of a given tradition. On its own, however, this would simply amount to a claim of unintelligibility, essentially an abandonment of the task of interpretation. Rather, understanding is generated out of Gadamer's celebrated 'fusion of horizons': not the permanent or final melding together of past and present, but rather the incessant movement of interplay, intersection and mediation between the poles of historical strangeness and familiarity. This in-betweenness, striving to maintain the tension as well as to mediate between 'alienating distantiation' and belonging, is constitutive of the hermeneutical approach. Mediation comes out of the sense of 'contemporaneity', of participation in and belonging to a living tradition out of which meaning is forged (Gadamer, 1975: 315, 1994: 86, 97-8, 117-21, 127-8, 132-4, 156-7, 161-5, 282-3, 295, 306-7, 390-1, 397, 537; Ricoeur, 1981b: 64-5).

Correspondingly, the ethnological imagination cannot remain fixed at the stage where alterity is respected for its own sake or even where one steers away from ethnocentric universalism. Tacitly or directly, the insulation of differences from each other supports a misleading belief in the complete incommensurability or untranslatability of cultures - itself a form of intercultural closure ontologizing otherness. ${ }^{15}$ Instead, sociology must put into practice the 'fusion of horizons', much in the manner suggested by Taylor's (1985b: 125) concept of 'perspicuous contrast' between different cultures:

This would be a language in which we could formulate both their way of life and ours as alternative possibilities in relation to some human constants at work in both. It would be a language in which the possible human variations would be so formulated that both our form of life and theirs could be perspicuously described as alternative to such variations.

The decentring of one's historico-cultural perspective makes way for the possibility of placing two or more sociocultural constellations along the same plane of intelligibility, from which the dialogical activities of contrast and comparison between them can flourish (Arnason, 1992: 256; Calhoun, 1995: 48-9, 80-2; Dumont, 1977: 15-16; Gadamer, 1994: 387-8, 537; Merleau-Ponty, 1953a: 100, 114, 1953b: 166, 1960: 153; Rabinow and Sullivan, 1987: 19; Ricoeur, 1981a: 62). Sociology can act as a vehicle of cultural mediation, studying the parallels as well as the divergences 
between different clusters of thinking and acting. If a productive tension between the familiar and the alien is thereby maintained, sociological research can also contribute to broadening the known scope of humanity's expressions of sociocultural instituting. In turn, the ethnological imagination can enhance our vision of the human mosaic, intimately associating sociology with the project of understanding the human condition - that incredible and endlessly varied articulation of identity and otherness, of closeness and distance (Bourdieu, 1990: 15; Bourdieu et al., 1991: 19-20; Diamond, 1974: 100, 211-12; Eliade, 1960: 9-12, 38; Elias, 1978: 104; Merleau-Ponty, 1953a: 113, 117, 121, 1953b: 166, 1960: 150; Mills, 1959: 6-8, 132-4; Park, 1950e: 253-4; Ricoeur, 1974: 52; Winch, 1970: 102, 106; Wolf, 1974: xiii).

\section{Reflexivity and the Inward Turn}

Intercultural sociology comes full circle by embarking upon an inward turn or moment of reflexivity. The preceding discussion of our field's potential for cultural mediation has underlined the advantages of an expanded worldview, notably in enlarging and deepening our appreciation of the panoply of possible human institutions. From this state of 'inbetweenness' arises the crucial Tocquevillian point of 'turning the mirror on ourselves' (Dumont, 1977: 23) and examining our habitus as a partially estranged reality. Indeed, the cross-cultural act of distancing and subsequent rapprochement from our original surroundings can further reflexive attempts to 'break the spell of our own fore-meanings' and overcome 'the tyranny of hidden prejudices'. Not, it should be pointed out, by naively trying to desert norms and habits acquired through socialization, but rather by foregrounding them; that is, by unveiling the frequently takenfor-granted assumptions that enable us to give meaning to the world. Sociological analysis of one's cultural environment requires precisely this type of self-reflexive vigilance, a critical intimacy with one's habitus that is born from in-depth knowledge of its symbolic and material structures. Thus, to be fully effective, the ethnological imagination's 'distancing effect' in relation to a specific cultural lifeworld can be tempered by a selfconscious involvement derived from first-hand experience, so as not to slip into complete alienation or utter remoteness (Elias, 1987b: 13; Gadamer, 1994: 14, 114, 268-70, 299, 441-2, 447-8; Merleau-Ponty, 1953a: 115, 1953b: 163; Ricoeur, 1981a: 62; Taylor, 1985a: 54, 57; Walzer, 1987: 39, 61-2). Put differently, it is the amalgamation of distance and proximity, not distance as such, that stimulates insightful sociologies of Western and non-Western contexts.

With a vaster outlook arising out of engagement with and mediation between cultures, the sociologist is now in a position to 'ethnologize' his or her own society, to effect a 'reversal of the ethnological perspective' 
(Fuchs, 1993). Implied by this inward turn are two premises foreshadowed earlier: putting into perspective our normative criteria of comparative assessment and our ways of life more generally, to which is added a reflexive familiarity with them. The specificity of Western modernity's sociocultural configurations, for instance, strongly comes into relief after being contrasted with those of non-modern and non-Western societies. Cross-cultural sociology revels in the play of involvement and detachment, the simultaneity of proximity and distance revealing surprising relations where the obvious, the banal and the normal were believed to silently reign (Bourdieu, 1990: 20; Merleau-Ponty, 1953a: 121). Not unlike Simmel's (1950) stranger who combines 'nearness and remoteness' or, yet again, Park's (1950b: 51) 'marginal man [sic]' who 'lives in two worlds but is not quite at home in either', the ethnologically minded sociologist acts neither as pure insider nor outsider, neither native nor foreigner; more accurately, he or she should be characterized as simultaneously insider outside and outsider inside a given culture. A step is taken back in order to take another forward, the sociologist temporarily removing himself or herself from surrounding cultural contexts in order to plunge back into the maelstrom.

This liminal state represents one of the means to concretize Bourdieu's demand that a rupture be established with the 'doxa' of one's social fields of action. Because they are inherited and shaped by a habitual lifeworld, routine practices and beliefs acquire an apparent self-evidence and 'naturalness'. Transformed into 'common sense' and 'second nature', they have been depoliticized, deculturalized and dehistoricized and are widely perceived to be immune from the inherent contingency of historical and cultural forces. Being recontextualized from the outside, yet known from the inside, our doxic experience becomes both defamiliarized and refamiliarized, prompting its comparative uncanniness (Unheimlichkeit) and exceptionalism to shine forth. Interculturally, the peculiarities of the modern West become too glaring to ignore and are decisively in need of explanation (Bourdieu, 1977: 3, 164-70, 1990: 26, 36, 139; Bourdieu et al., 1991: 13-15, 19-20, 249; Bourdieu and Wacquant, 1992: 73-4; Calhoun, 1995: 48; Castoriadis, 1997: 101; Dumont, 1986: 207; Elias, 1987b: 14-16; Merleau-Ponty, 1953a: 100, 1960: 150-1; Mills, 1959: 7-8; Park, 1950b: 49-50, 1950f: 306-7).

The ethnological imagination's inward turn has illuminated and arguably given birth to some of the central concepts and processes that inform the sociological outlook. Among others, industrialization, capitalism, urbanization, rationalization, alienation, anomie and individuation are scarcely conceivable without the counter-factual reflection provided by the non-modern and the non-Western world. The extent to which such diagnoses can be pluralized, transformed and qualified to accommodate 
humankind's diversity remains one of the questions facing a properly intercultural sociology.

\section{Conclusion}

The ethnological counter-current has, I believe, played an essential yet chronically underrated role throughout sociology's history. As we turn the page on the 20th century, it behooves our discipline to revisit the crosscultural impulse of its founders - that of reaching out beyond their own societies' borders to gain a better appreciation of the dynamics that refashioned the North Atlantic region with the advent of modernity. Continuing to address Gauguin's queries, the ethnological imagination can also enable us to stay clear of the twin temptations of simplistic idealization or denigration of any society, of resorting to the ready-made tropes of Orientalism, primitivism, or even Occidentalism. On the contrary, it fosters an intellectual atmosphere that welcomes critical engagement with other cultures and strives toward mutual understanding and respect.

In an aphorism aptly entitled 'Savages are Not More Noble', Adorno (1974: 52) wrote something along these lines: 'An uncompromising mind is the very opposite of primitivism, neophytism, or the "non-capitalist world". It presupposes experience, a historical memory, a fastidious intellect and above all an ample measure of satiety.' A modest demand, perhaps, albeit a literally radical one: the willingness to always confront and encounter anew other cultural horizons brings us to question the roots of our own societies and envision a plurality of modernities; in short, the very spirit of cross-cultural sociology.

\section{Notes}

For their comments on earlier versions of this article, I thank Johann Arnason, Peter Beilharz, Joel Kahn, Vince Marotta, Rayna Rapp, the anonymous referees for International Sociology and the participants at the following fora during which it was presented: the Annual Conference, School of Sociology, Politics and Anthropology, La Trobe University (October 1998); the Alternative Modernities Conference, Ashworth Centre for Social Theory, University of Melbourne (November 1998); and the Culture Roundtable, Departments of Sociology and Anthropology, New School for Social Research (March 1999).

1. Although he alludes to the contrary, Elias himself does not question wellestablished disciplinary fields: 'Anthropologists, in most cases, study societies to which they do not belong, other sociologists, mostly societies of which they are members' (Elias, 1987b: 40 n.4).

2. Involvement and detachment are not the only sociological approaches that offer a capacity to problematize modernity. They have, nonetheless, been among the most rewarding ways of doing so. 
3. During the first decades of the 20th century, Park and fellow members of the Chicago School pioneered another instance of the ethnological imagination within sociology, namely the study of communities of color (AfricanAmericans, Japanese-Americans, etc.) as a way to view 'mainstream' American society differently. Park pointed to the absence of a direct correspondence between society, nation and culture - and in particular, the fact that society (assumed to be a nationally bound object of sociological analysis) contains a multiplicity of cultures. Consequently, the ethnological imagination can be supported by a multicultural perspective, 'looking elsewhere' rather than obligatorily 'going abroad'. This opens up an interesting aspect of the question, which cannot be further explored in this article.

One should also add that, although not directly related to the ethnological imagination, Simmel's (1950) notion of the stranger and Park's (1950b: 51) concept of the 'marginal man [sic]' considerably overlap with it (as discussed later in this article). To put it succinctly, while the conditions fostering the stranger's, the marginal woman or man's or the social analyst's position may differ, the effects are akin. I thank Vince Marotta for drawing my attention to this point.

4. Elias's ability to generate a 'distancing effect' vis-a-vis the modern West is thus related much more closely to genealogical than to cross-cultural critique. Detachment is pursued along a historical rather than ethnological axis of contrast and comparison, setting it in opposition to Lévi-Strauss's (1985) 'view from afar'. Nonetheless, in a passage from an interview during which he discusses his years in Ghana (1962-4), Elias (1994b: 68-72) does indicate the impact of his encounter with the non-Western world on his thinking.

5. Obviously, this is not to argue that the 'primitive' and 'Oriental' conditions are the sole alternative cultural horizons against which Western modernity has formed and interpreted itself, nor that these were homogeneous entities. A comprehensive survey of such horizons would need to take into consideration at least three other imagined cultures: Judaism (for Christianity), ancient Greece (for classicism) and the European Middle Ages (for Romantic pastoralism); on the impact of the latter two within sociology, see Gouldner (1973). Furthermore, both primitiveness and the 'Orient' are composed of multiple cultures whose modes and moments of historical interaction with the modern West contain their own specificities: for the first, South and North American indigenous peoples, East and West Africans, South Pacific and Australian Aborigines, etc.; for the second, India, China, Japan, etc.

6. I partly follow Eliade in employing the notion of myth not in contradistinction to truth or reality, but rather in the widest anthropological sense: a narrated set of beliefs which is viewed as a truthful, sacred and repeatable explanation of the origins of humanity. It is used to make sense of, give meaning to and transmit specific versions of the past, the present and the future of a culture to its members (Eliade, 1960: 23-4).

7. At this point, three caveats should be advanced. I do not claim that the ethnological imagination is a feature unique to Western modernity - and this in two senses: first, its existence considerably precedes the modern epoch, since it can be traced back to Greek antiquity and the European Middle Ages (Boas, 1948; 
Lovejoy and Boas, 1935); second, it is not an exclusively Western phenomenon, but one which has been developed in many (though certainly not all) non-Western cultures. Lastly, the modern West's engagement with cultural alterity is inseparable from - though emphatically not reducible to - historical patterns of Western self-expansion (colonialism and imperialism). By way of racism and some species of nationalism, such engagement has contributed to Western modernity's sense of superiority vis-a-vis other cultures. In light of the fact that it is only concerned with the use of cross-cultural theorizing to effect a self-critique of the modern West, the ethnological imagination excludes this aspect of the question.

8. Illustrating the central contention of this article, these queries were imagined, or rather dared to be imagined, during Gauguin's return sojourn to Tahiti the 'primitive' being intertwined with the modern (Gauguin, 1968: 69-72). It is also significant that Gauguin is widely recognized as the first primitivist in the history of modern European visual arts (Goldwater, 1986: 63-4; Rubin, 1984: 7).

9. As Montesquieu himself explained in a postscript written more than 30 years later: 'He [the reader] is also asked to bear in mind that the whole effect was due to the perpetual contrast between the reality of things and the odd, naive, or strange way in which they were perceived' (Montesquieu, 1973: 284). Walzer has observed that: 'it is Montesquieu, the well-connected Frenchman, not Usbek, who is the social critic. Persian naiveté is a mask for French sophistication' (Walzer, 1987: 39).

10. In The Order of Things, Foucault stated that ethnology represented one of the two disciplinary fields that makes explicit the structures and contours of European thought:

Psychoanalysis and ethnology occupy a privileged position in our knowledge ... because, in the confines of all the branches of knowledge investigating man, they form an undoubted and inexhaustible treasurehoard of experiences and concepts, and above all a perpetual principle of dissatisfaction, of calling into question, of criticism and contestation of what may seem, in other respects, to be established'. (Foucault, 1970: 373)

11. Dumont claims that:

Most often, what has been attempted up until now in terms of comparison is centred on the modern case: why did such and such of the other great civilizations not develop the science of nature, or technology, or capitalism, that is found in ours? The question has to be reversed: how and why did this unique development that we call modern occur? The central comparative task consists in accounting for the modern type on the basis of the traditional type. (Dumont, 1977: 15-16; see also Dumont, 1986: 4, 23, 1994: 6-7)

For an excellent critique of both the substantive claims and the perspective adopted by Dumont, see Fuchs (1993: 112-18). Rabinow (1996: 36) concisely expresses the ethnological imagination's purpose: 
We need to anthropologize the West: show how exotic its constitution of reality has been; emphasize those domains most taken for granted as universal (this includes epistemology and economics); make them seem as historically peculiar as possible; show how their claims to truth are linked to social practices and have hence become effective forces in the social world.

12. The task of providing a full exploration of the rich tradition of hermeneutics, as well as of its relationship to phenomenology, goes well beyond the scope of this article. As such, I am solely concerned with applying specific hermeneutical insights to enrich my account of sociology's ethnological imagination. Obviously, hermeneutics is not a homogeneous philosophical paradigm, the differences and debates between its major practitioners being numerous. Consequently, my attention is focused upon four specific authors located within the hermeneutical tradition, namely Merleau-Ponty, Gadamer, Ricoeur and Taylor.

13. The figurative and literal modes of temporary escape cannot be neatly separated from one another, as they are, in fact, interwoven; a person traveling to a non-Western society already carries with her or him a particular set of expectations, preconceptions and images, while one who 'stays at home' and simply devises an imaginary alter ego to Western modernity is influenced by existing accounts of non-Western societies.

14. Although Gadamer limits his remarks to the historical realm, he also indicates that a broader conception of distance - one that could incorporate cultural distance - is entirely feasible: 'it is distance, not only temporal distance, that makes this hermeneutic problem solvable' (Gadamer, 1994: 298, f.n.228). Moreover, his numerous comparisons between interpretation and translation reinforce the impression that he is aware of the intercultural implications of his thinking.

15. This is why Winch's (1970) widely debated late-Wittgensteinian position regarding the ultimate untranslatability and unintelligibility of primitive institutions from a modern Western perspective is unconvincing - as is some 'postmodern' theorizing which has subsequently supported the thesis of radical incommensurability between cultures and, consequently, of absolute cultural relativism.

\section{References}

Adorno, T. (1974) Minima Moralia: Reflections from Damaged Life, trans E. F. N. Jephcott. London: Verso. (Orig. pub. 1951.)

Arnason, J. P. (1990) ‘Modernity as Project and as Field of Tensions', in A. Honneth and H. Joas (eds) Communicative Action: Essays on Jürgen Habermas's The Theory of Communicative Action, trans. J. Gaines and D. L. Jones. Cambridge, MA: MIT Press.

Arnason, J. P. (1992) 'World Interpretation and Mutual Understanding', in A. Honneth, T. McCarthy, C. Offe and A. Wellmer (eds) Cultural-Political 
Interventions in the Unfinished Project of Enlightenment, trans. B. Fultner. Cambridge, MA: MIT Press.

Asad, T. (1993) Genealogies of Religion: Discipline and Reasons of Power in Christianity and Islam. Baltimore, MD: Johns Hopkins University Press.

Augé, M. (1995) Non-Places: Introduction to an Anthropology of Supermodernity, trans. J. Howe. London: Verso. (Orig. pub. 1992.)

Augé, M. (1998) A Sense for the Other: The Timeliness and Relevance of Anthropology, trans. A. Jacobs. Stanford, CA: Stanford University Press. (Orig. pub. 1994.)

Boas, G. (1948) Primitivism and Related Ideas in the Middle Ages. Baltimore, MD: Johns Hopkins University Press.

Bourdieu, P. (1977) Outline of a Theory of Practice, trans. R. Nice. Cambridge: Cambridge University Press. (Orig. pub. 1972.)

Bourdieu, P. (1979) La Distinction: critique sociale du jugement [Distinction: A Social Critique of the Judgment of Taste]. Paris: Minuit.

Bourdieu, P. (1988) Homo Academicus, trans. P. Collier. Cambridge: Polity. (Orig. pub. 1984.)

Bourdieu, P. (1990) The Logic of Practice, trans. R. Nice. Cambridge: Polity. (Orig. pub. 1980.)

Bourdieu, P. and Wacquant, L.J.D. (1992) An Invitation to Reflexive Sociology. Chicago, IL: University of Chicago Press.

Bourdieu, P., Chamboredon, J.-C. and Passeron, J.-C. (1991) The Craft of Sociology: Epistemological Preliminaries, ed. B. Krais, trans. R. Nice. Berlin and New York: de Gruyter. (Orig. pub. 1968.)

Calhoun, C. (1995) Critical Social Theory: Culture, History, and the Challenge of Difference. Oxford: Blackwell.

Castoriadis, C. (1997) 'Anthropology, Philosophy, Politics', trans. D. A. Curtis, Thesis Eleven 49: 99-116. (Orig. pub. 1990.)

Clastres, P. (1977) Society Against the State, trans. R. Hurley and A. Stein. Oxford: Blackwell. (Orig. pub. 1974.)

Derrida, J. (1978) 'Structure, Sign and Play in the Discourse of the Human Sciences', Writing and Difference, trans. A. Bass. London: Routledge. (Orig. pub. 1967.)

Diamond, S. (1974) In Search of the Primitive: A Critique of Civilization. New Brunswick, NJ: Transaction.

Dumont, L. (1972) Homo Hierarchicus: The Caste System and its Implications. London: Paladin. (Orig. pub. 1966.)

Dumont, L. (1977) Homo aequalis I: Genèse et épanouissement de l'idéologie économique [From Mandeville to Marx: The Genesis and Triumph of Economic Ideology]. Paris: Gallimard.

Dumont, L. (1986) Essays on Individualism: Modern Ideology in Anthropological Perspective. Chicago, IL: University of Chicago Press.

Dumont, L. (1994) German Ideology: From France to Germany and Back. Chicago, IL: University of Chicago Press.

Eliade, M. (1960) Myths, Dreams and Mysteries: The Encounter Between Contemporary Faiths and Archaic Realities, trans. P. Mairet. New York: Harper and Row. (Orig. pub. 1957.) 
Elias, N. (1978) What Is Sociology?, trans. S. Mennell and G. Morrissey. London: Hutchinson. (Orig. pub. 1970.)

Elias, N. (1987a) 'The Retreat of Sociologists into the Present', Theory, Culture $\mathcal{E}$ Society 4(2-3): 223-47.

Elias, N. (1987b) Involvement and Detachment, trans. E. Jephcott. Oxford: Blackwell (Orig. pub. 1983.).

Elias, N. (1994a) The Civilizing Process, trans. E. Jephcott. Oxford: Blackwell. (Orig. pub. 1939.)

Elias, N. (1994b) Reflections on a Life, trans. E. Jephcott. Cambridge: Polity. (Orig. pub. 1987.)

Foucault, M. (1965) Madness and Civilization: A History of Insanity in the Age of Reason, trans. R. Howard. New York: Vintage. (Orig. pub. 1961.)

Foucault, M. (1970) The Order of Things: An Archaeology of the Human Sciences, anonymous translation. New York: Vintage. (Orig. pub. 1966.)

Foucault, M. (1977) Discipline and Punish: The Birth of the Prison, trans. A. Sheridan. London: Allen Lane. (Orig. pub. 1975.)

Foucault, M. (1978) The History of Sexuality, Volume 1: An Introduction, trans. R. Hurley. New York: Vintage. (Orig. pub. 1976.)

Fuchs, M. (1993) 'The Reversal of the Ethnological Perspective: Attempts at Objectifying One's Own Cultural Horizon: Dumont, Foucault, Bourdieu', trans. C. Harshvardhan, Thesis Eleven 34: 104-25. (Orig. pub. 1991.)

Gadamer, H.-G. (1975) 'Hermeneutics and Social Science', Cultural Hermeneutics 2(4): 307-16.

Gadamer, H.-G. (1994) Truth and Method, 2nd edn, trans. J. Weinsheimer and D. G. Marshall. New York: Continuum. (Orig. pub. 1960.)

Gauguin, P. (1968) 'Where Do We Come From? What Are We? Where Are We Going?', in H. B. Chipp (ed.) Theories of Modern Art: A Source Book by Artists and Critics. Berkeley and Los Angeles: University of California Press. (Orig. pub. 1898.)

Goldwater, R. (1986) Primitivism in Modern Art, enlarged edn. Cambridge, MA: Harvard University Press. (Orig. pub. 1938.)

Gouldner, A. W. (1973) 'Romanticism and Classicism: Deep Structures in Social Science', For Sociology: Renewal and Critique in Sociology Today. London: Allen Lane.

Heller, A. (1982) A Theory of History. London: Routledge \& Kegan Paul.

Herder, J. G. (1966) Outlines of a Philosophy of the History of Man, trans. T. Churchill. New York: Bergman. (Orig. pub. 1784.)

Horkheimer, M. (1972) 'Traditional and Critical Theory', Critical Theory: Selected Essays, trans. M.J. O'Connell. New York: Seabury. (Orig. pub. 1968.)

Lévi-Strauss, C. (1968) 'The Concept of Archaism in Anthropology', Structural Anthropology, Volume 1, trans. C. Jacobson and B.G. Schoepf. Harmondsworth: Penguin. (Orig. pub. 1958.)

Lévi-Strauss, C. (1985) The View from Afar, trans. J. Neugroschel and P. Hoss. Oxford: Blackwell. (Orig. pub. 1983.)

Lévi-Strauss, C. et al. (1970) 'A Confrontation', New Left Review 62: 57-74.

Lovejoy, A. O. and Boas, G. (1935) Primitivism and Related Ideas in Antiquity. Baltimore, MD: Johns Hopkins University Press. 
Lyotard, J.-F. (1984) The Postmodern Condition: A Report on Knowledge, trans. G. Bennington and B. Massumi. Minneapolis, MN: University of Minnesota Press. (Orig. pub. 1979.)

Marcus, G. E. and Fischer, M. M. J. (1986) Anthropology as Cultural Critique: An Experimental Moment in the Human Sciences. Chicago, IL: University of Chicago Press.

Merleau-Ponty, M. (1953a) 'Le philosophe et la sociologie' [The Philosopher and Sociology], Éloge de la philosophie et autres essais [In Praise of Philosophy and Other Essays]. Paris: Gallimard.

Merleau-Ponty, M. (1953b) 'Partout et nulle part' [Everywhere and Nowhere], Éloge de la philosophie et autres essais [In Praise of Philosophy and Other Essays]. Paris: Gallimard.

Merleau-Ponty, M. (1960) 'De Mauss à Claude Lévi-Strauss' [From Mauss to Claude Lévi-Strauss], Signes. Paris: Gallimard.

Mills, C. W. (1959) The Sociological Imagination. Oxford: Oxford University Press.

Montaigne, M. de (1948) 'Of Cannibals', in The Complete Works of Montaigne, trans. D. M. Frame. Stanford, CA: Stanford University Press. (Orig. pub. 1578-80.)

Montesquieu, C. de S. (1973) Persian Letters, trans. C. J. Betts. Harmondsworth: Penguin. (Orig. pub. 1721.)

Park, R. E. (1950a) 'The Problem of Cultural Differences', Race and Culture: The Collected Papers of Robert Ezra Park, Vol. I. Glencoe, IL: Free Press. (Orig. pub. 1931.)

Park, R. E. (1950b) 'Reflections on Communication and Culture', Race and Culture: The Collected Papers of Robert Ezra Park, Vol. I. Glencoe, IL: Free Press. (Orig. pub. 1938.)

Park, R. E. (1950c) 'The Nature of Race Relations', Race and Culture: The Collected Papers of Robert Ezra Park, Vol. I. Glencoe, IL: Free Press. (Orig. pub. 1939.)

Park, R. E. (1950d) 'Racial Assimilation in Secondary Groups', Race and Culture: The Collected Papers of Robert Ezra Park, Vol. I. Glencoe, IL: Free Press. (Orig. pub. 1913.)

Park, R. E. (1950e) 'Behind our Masks', Race and Culture: The Collected Papers of Robert Ezra Park, Vol. I. Glencoe, IL: Free Press. (Orig. pub. 1926.)

Park, R. E. (1950f) 'Race Ideologies', Race and Culture: The Collected Papers of Robert Ezra Park, Vol. I. Glencoe, IL: Free Press. (Orig. pub. 1943.)

Park, R. E. (1952) Human Communities: The Collected Papers of Robert Ezra Park, Vol. II. Glencoe, IL: Free Press.

Rabinow, P. (1996) Essays on the Anthropology of Reason. Princeton, NJ: Princeton University Press.

Rabinow, P. and Sullivan, W. M. (1987) 'The Interpretive Turn: A Second Look', in P. Rabinow and W.M. Sullivan (eds) Interpretive Social Science: A Second Look. Berkeley, CA: University of California Press.

Ricoeur, P. (1974) 'Structure and Hermeneutics', in D. Ihde (ed.) The Conflict of Interpretations: Essays in Hermeneutics. Evanston, IL: Northwestern University Press. (Orig. pub. 1969.)

Ricoeur, P. (1981a) 'The Task of Hermeneutics', in J.B. Thompson (ed., trans.) Hermeneutics and the Human Sciences: Essays on Language, Action and Interpretation. Cambridge: Cambridge University Press. 
Ricoeur, P. (1981b) 'Hermeneutics and the Critique of Ideology', in J.B. Thompson (ed., trans.) Hermeneutics and the Human Sciences: Essays on Language, Action and Interpretation. Cambridge: Cambridge University Press.

Ricoeur, P. (1981c) 'The Hermeneutical Function of Distantiation', in J.B. Thompson (ed., trans.) Hermeneutics and the Human Sciences: Essays on Language, Action and Interpretation. Cambridge: Cambridge University Press.

Rubin, W. (1984) 'Modernist Primitivism: An Introduction', in W. Rubin (ed.) 'Primitivism' in 20th Century Art: Affinity of the Tribal and the Modern. New York: Museum of Modern Art.

Simmel, G. (1950) 'The Stranger', in K.H. Wolff (ed., trans.) The Sociology of Georg Simmel. New York: Free Press.

Taylor, C. (1985a) 'Interpretation and the Sciences of Man', Philosophy and the Human Sciences: Philosophical Papers 2. Cambridge: Cambridge University Press.

Taylor, C. (1985b) 'Understanding and Ethnocentricity', Philosophy and the Human Sciences: Philosophical Papers 2. Cambridge: Cambridge University Press.

Taylor, C. (1989) Sources of the Self: The Making of the Modern Identity. Cambridge, MA: Harvard University Press.

Taylor, C. (1998) 'From Philosophical Anthropology to the Politics of Recognition: An Interview with Charles Taylor', trans. S. Rothnie, Thesis Eleven 52: 103-12.

Walzer, M. (1987) Interpretation and Social Criticism. Cambridge, MA: Harvard University Press.

Winch, P. (1970) 'Understanding a Primitive Society', in B.R. Wilson (ed.) Rationality. Oxford: Blackwell.

Wolf, E.R. (1974) 'Foreword', in S. Diamond (ed.) In Search of the Primitive: A Critique of Civilization. New Brunswick, NJ: Transaction.

Biographical Note: Fuyuki Kurasawa is a Commonwealth Fellow and PhD candidate in the School of Sociology, Politics and Anthropology at La Trobe University, Melbourne, Australia and a Visiting Fellow at Carleton University, Ottawa, Canada. His most recent publications include 'The Adventures of the Structure', Thesis Eleven 55 (1998); 'The Exotic Effect: Foucault and the Question of Cultural Alterity', European Journal of Social Theory 2(2) (1999); 'At the Crossroads of the Radical: The Challenges of Castoriadis's Thought', Theory, Culture $\mathcal{E}$ Society 17 (2000). He has also translated, inter alia, articles on Norbert Elias and by Cornelius Castoriadis.

Address: Institute of Political Economy, Room A818 Loeb Building, Carleton University, 1125 Colonel By Drive, Ottawa, Ontario K1S 5B6 Canada. [email: fkurasawa@yahoo.com] 